$12-31-2020$

\title{
The 21st century global digital economies revolution and the aftermath of COVID-19 pandemic: Some anticipated implication changes for developing nations
}

Agyei Fosu

Walter Sisulu University, South Africa, afosu@wsu.ac.za

Follow this and additional works at: https://scholarhub.ui.ac.id/ajce

Part of the Health Information Technology Commons, and the Social and Behavioral Sciences Commons

\section{Recommended Citation}

Fosu, Agyei (2020). The 21st century global digital economies revolution and the aftermath of COVID-19 pandemic: Some anticipated implication changes for developing nations. ASEAN Journal of Community Engagement, 4(2), 435-451.

Available at: https://doi.org/10.7454/ajce.v4i2.1113

Creative Commons License

(c) (i) (2)

This work is licensed under a Creative Commons Attribution-Share Alike 4.0 License.

This Review Article is brought to you for free and open access by the Universitas Indonesia at ASEAN Journal of Community Engagement. It has been accepted for inclusion in ASEAN Journal of Community Engagement. 


\title{
The 21st century global digital economies revolution and the aftermath of COVID-19 pandemic: Some anticipated implication changes for developing nations
}

\author{
Agyei Fosu $\mathrm{a}^{*}$ \\ ${ }^{a}$ Walter Sisulu University, South Africa \\ Received: November 4th 2020 || Revised: November 23 ${ }^{\text {rd }}$ and December 16 ${ }^{\text {th }}, 2020||$ Accepted: December $30^{\text {th }}, 2020$
}

\begin{abstract}
The $21^{\text {st }}$ century digital global economies era changed developmental approaches drastically to a point where most researchers, policy makers, and developers have asserted that to achieve economic development for developing nations; it is paramount for Information and Communications Technologies (ICTs) investments in all sectors contributing to their economy. The current COVID-19 pandemic and the various measures taken by governments such as lockdown, curfew, companies asking employees to work from home, and the use of e-learning by schools to curb the disease brings into perspective the assertion raised by various scholars about the need for developing nations to invest in ICTs in order to stimulate economic development. In line with this assertion from various authors, the author of this article believes that the following two questions are critical for planners, policy developers, and agents of change for economic development, especially for developing nations: first, how are the COVID-19 pandemic and the measures such as lockdown, curfew, and isolation taken by various governments and corporate bodies going to fuel the already in motion global wave of the 21st century digital economies revolution propelled by the rapid development in ICTs and its devices? Second, how will ICTs investment and ICTs leverage foster development in economic sectors in developing nations' economies? Thus, this article will look at some anticipated implication changes in terms of ICTs investments and sectors in a developing nation's economy that will see or need these massive non-negotiable ICTs investments and leveraging of ICTs in order to foster economic growth and development.
\end{abstract}

Keywords: digital economies revolution; COVID-19; pandemic; developing nations.

\section{Introduction}

Every evolution and revolution in any economy brings about non-avoidable ripple change effect in sectors within that economy. The global wave of the 21st century digital economies revolution had already set-in motion some ripple implication changes for major sectors like education and corporate bodies in developing nation's economies. However, these changes for such players in a developing nation's economy have been relatively slow in its emergencies due to various factors (Wilson \& Heeks, 2000). The current COVID-19 pandemic and measures taken by governments of both developed and developing nations to curb the spread of the disease, such as national lockdown, have spiked and will fuel as well as compel governments,

\footnotetext{
*Correspondence Author: afosu@wsu.ac.za
} 
business entities, and other sectors in developing nations to fasten the changes set in motion by the 21st century global digital economies revolution.

Working, getting education, and doing business in the 21st century global digital economies revolution is radically different from the previous century. Presence at work or at school under the current era is not just about proximity. Presence is all about being able to fulfil or achieve the expected results irrespective of proximity, and this assertion is seen in the continual messages and measures taken by various governments and corporate bodies encouraging people and workers to stay and work from home to help curb the pandemic. These initiatives and measures somehow are ushering in the full wave of the 21st century global digital economies revolution implication changes that are non-avoidable integration of ICTs and its devices into business activities, teaching and learning, and other integrations thereby requiring some ICTs investments. This paper shows some sectors anticipated to see implications, rapid ICTs investments, and leveraging of ICTs in developing nations' economy globally.

According to Yosuf (2001) similar economic challenges confront developing nations. Several sectors feeds developing nation's economy however education, agriculture, health, manufacturing, and rural development are critical for emphasis due to their vital role in human wellbeing hence sustainability of these sectors is paramount to maintain.

\section{Methods}

Two approaches were used in this study: observation and systematic literature review approach. The author in this study resides in a developing nation, thus, making it easier for him to assume the role of an observer since he is familiar with issues affecting developing nations.

Topic-centric according to Webster and Watson (2002) is a relevant way when using a systematic literature review approach in assessing and classifying literature. In this approach, the author defines the topics that will guide the search and the search strategy. The author intends to analyse existing literature on how ICTs investment and ICTs leverage foster economic sector development in developing nations in two dimensions: first, by investigating the challenges facing the selected economic sectors (education, agriculture, health, manufacturing, and rural development) and second, by looking at how leveraging technology contributes to the development of the selected economic sectors.

The logical search process (Tranfield et al., 2003) was used. The keywords "developing nations," "ICTs investment and leveraging ICTs," and "socio-economic development" guided the search, which led to a search for literature cutting across many disciplines such as development 
Agyei Fosu | ASEAN Journal of Community Engagement | Volume 4, Number 2, 2020

studies, education, management, information management, and entrepreneurship. Relevant literature was identified and synthesized.

\section{Results and Discussion}

\subsection{Higher education sector}

Kinuthia and Dagada (2008) pointed out that one of the major roles of the higher education sector is to ensure that graduates are suited to and competent for the specialized labour skills required by the industrial sector. In line with this role, it is critical to tailor methodologies/approaches used in teaching or training students in higher education institutions to meet the required global emerging market skills. Oxagile (2016) stated that the mode of higher education training changed and entered a new phase with the introduction of educational technologies. We are in the Fourth Industrial Revolution. Murphy et al. (2001) stated how the integration of technology not only supports the conventional approach of lecturing courses in higher education institutions but also offsets changes required by the 21st century global digital economies from the higher education sector.

Literature reveal how most higher education institutions from developed countries started investing and integrating computer or technology into their teaching and learning environment as early as late1900-2000 (Hodgkinson-Williams, 2008; Oxagile, 2006; Rosenberg, 2001; Zhao et al., 2009). This is not the case for developing nations, however, since transformations have been very slow because of various factors. For instance, Hodgkinson-Williams et al. (2008) highlighted that although higher education institutions have been using e-learning globally, not all cultural groupings in various countries in Middle East have seen much technological integration. Alshara and Alsharo (2007) also pointed out that the slow rate of technological integration, especially in Jordan and UAE, can be partially attributed to two factors: challenges in developing practical as well as implementation of e-learning programs. On the other hand, Qteishat and Alshibly (2013) showed a general positive attitude from both students and administrators toward e-learning in higher education institutions in Turkey.

Africa with its many developing nations has similar stories with other developing countries in other continents. In Ghana, some of its higher education institutions, such as the University of Education, Winneba (UEW), Kwame Nkrumah University of Science and Technology (KNUST), and the University of Professional Studies of Accra, are using educational technologies together with traditional methods of lecturing as a strategic tool for managing the growing number of students accessing tertiary education in recent years (Asampana et al., 
2017; Marfo \& Okine, 2010). A study conducted by Maina and Nzuki (2015) in five universities within Nairobi Metropolitan, Kenya revealed that expected performance, enabling infrastructures, institutional policies, training support, leadership, and ease of effort use influence the adoption of web-based learning management system in the universities.

Calitz (2000) highlighted the lack of support for educators in most African educational institutions, especially in areas where provision of modern teaching tools is necessary, which is due to lack of state funding. Other researchers such as Alias et al. (2005), Macedo-Rouet (2009), and Fosu (2019a) have also highlighted challenges that hinder technology integration into teaching and learning environment in higher education institutions in developing nations especially those in Africa. These challenges include inadequate training of lecturers and students, high cost of technology, poor IT infrastructure, unstable internet systems, unreliable electricity power supply, and poor decision.

\subsection{The relevance of technology integration into the teaching and learning environment: benefits to students}

Seena (2010) pointed out the much-needed labor skills in the 21st century digital era, such as knowledge, teamwork, e-skills, and communication skills, which students acquire when technology is integrated into the teaching and learning environment. Technology can aid students in searching and using information to complete assignments and projects and make presentations. In addition, using technology in projects and presentations provides students with vital hands-on e-skills that will be useful in the 21st century digital economies era where workplaces are saturated with technology and device usage (Fosu, 2019b).

The integration of technology into the teaching and learning environment of higher education institutions promotes inclusive education by offering other instructional approaches to support conventional approaches, thereby catering students who normally experience some barriers to learning and becomes slow learners. Furthermore, integration or investment in ICTs offers an opportunity to working students to access higher education and earn a living at the same time. It also eliminates the students' struggles to be physically present in the campus to access sources of knowledge. 
Agyei Fosu | ASEAN Journal of Community Engagement | Volume 4, Number 2, 2020

\subsection{Challenges facing higher education institutions in developing nations and how leveraging} technology can be a solution

Infrastructural issues such as restricted lecture halls and student's residence are resource constraints confronting higher education institutions in developing nations. Universities in developing nations tend to restrict admissions to a particular course because of infrastructural constraints and other restricting factors. Thus, qualifying students in developing nations commonly do not get to enroll in courses they are much interested in, especially if the demand for that course is high. Educational technologies and ICTs together with the conventional approach of delivering courses through lecturing would assist in eliminating infrastructural restrictions that prevent many prospect students from enrolling in courses and programs of their dreams. Phillipo and Krongard (2012) emphasized that an integration of technology into the teaching and learning environment serves as a catalyst to many current and future education initiatives, such as personalized learning, learner-centered decision-making, staff productivity, and curriculum development in line with educational reforms required from higher educational institutions in the 21st century digital era.

As asserted by Farrel (2001), any transformation in approaches of delivery of education should lead to an improvement of access to quality and equality of learning. Institutions of higher education in developing nations need to strive to make necessary changes required in line with the global changes because of the 21st century digital era waves because the learning patterns of the 21st century learners are evolving along with the continuous advancement of ICTs and its devices. Thus, utilization of technology and ICTs investment in the teaching and learning environment of higher education is non-avoidable in this era. Most higher education institutions in developing nations started providing laptops, routers, and data to students and staff during lockdown, investing in latest educational technologies to facilitate e-learning. Most higher education institutions in developing nations were left unprepared with the crisis of teaching and learning outside the four walls of their campuses in the Fourth Industrial Revolution, and this trend is expected to continue.

\subsection{Agricultural sector}

The agriculture sector has been identified globally as the backbone of the economy of most developing countries; thus, majority of developing nations' rural livelihood survives on agriculture (Stienen et al., 2007). With rising concerns of feeding an estimated worldwide population of nine billion by 2050 , a shift in focus to small-scale agribusiness to create 
sustainable livelihoods, employment, and curtail food insecurity in rural areas emerged (Bohara, 2008; Chavula, 2013; Chhachhar et al., 2014). Hence, increasing the efficiency, productivity, and sustainability of small-scale farms is critical to rural people and rural economy development. However, global warming and other factors affecting the environment plagued farmers around the globe with challenges in areas of poor soils, drought, erosion, and pests.

With threats such as pests, erosion, poor soil, and drought, farming is considered a risky occupation that bears uncertainty. Experts have highlighted the need of an innovative approach to help farmers deal with various threats and challenges confronting their occupation, especially small-scale farmers, to increase their productivity, and thereby improve rural livelihoods in developing nations.

Access to critical information from researchers, agricultural experts in the areas of pest and disease control, early warning systems, new varieties, new ways to optimize production and regulations for quality control are vital for farmers (Stienen et al., 2007). Hence, ICTs investment is important. Blending traditional and new ICTs can improve extension services and connect extension agents, farmers, and researchers. In developing nations, information pertaining to agriculture is normally accessed through agricultural extension officers and offices. With the lockdown imposed by various developing nations, most agricultural extension service offices were closed, leaving rural small-scale farmers to access agricultural information on websites. Farmers who opt for this approach may miss critical services offered by the extension services, which will likely impact food production.

Thus, governments from most developing nations would like to hasten ICTs investment in their agricultural sector. In identifying ways where ICTs investment can help small-scale farmers, it is useful to consider the three stages of farming:

a. Precultivation: the selection of crop, animal, land, etc.

b. Cultivation and harvesting: land preparation and seed sowing, breeding of animals, input management (fertilize application, pest control, animal vaccination, etc.).

c. Post harvesting: marketing, transportation, packaging, processing of farm produce, etc. Each stage requires a form of gathering and accessing essential information. Hence, access to and ICT usage can help bridge critical knowledge gaps most rural small-scale farmers' experience in the three-stage process of farming. 
Agyei Fosu | ASEAN Journal of Community Engagement | Volume 4, Number 2, 2020

\subsection{Available literature on how leveraging ICTs is improving developing nation's agricultural} sector

Access to information is one of the major keys in the era of knowledge-based economy as it facilitates the developmental path shifting from industrial toward where knowledge leads to creation of innovation, which then becomes the engine that drives economic growth. Information is critical to agricultural inputs. The use of information enhances productivity in several ways according to Bohara (2008). Information creates opportunities for farmers to access best farm practices, sources of financial aids, and new markets. Oluoch and Osida (2015) highlighted the inability of farmers to collect critical data efficiently and effectively about their farm produce and the expenses that arise from input. Common factors affected by pre-access to information on markets include farmers' decisions on the type of crops to plant, what inputs to buy, and markets to sell farm produce.

Unfortunately, according to Nzonzo and Mogambi (2016), most developing nations have not given much attention to providing their citizens, especially those living in rural areas, with access to information. Leveraging ICTs in terms of producing knowledge content and costeffective ways of distributing information and knowledge is a critical tool for developing human skills, which in turn leads to driving productivity and economic prosperity. Thus, leveraging ICTs becomes the beacon of hope in a developing nation's efforts to accelerate their development process (Nyamba and Mlozi, 2012). Das (2013) have also pointed out that ICTs serves as an effective platform to distribute agricultural knowledge. Katengeza (2012) asserted that ICTs intervention in agriculture have become efficient and cost-effective in communicating knowledge to rural farmers as well as serve as platforms to market their farm produce.

The use of ICTs among irrigated rice producers in both Malaysia and India in the studies of Hassan et al. (2009) and Syiem and Raj (2015) had shown positive effects on access to markets, sharing value addition activities in irrigated rice production. In addition, Halewood and Surya's (2012) study revealed that farmers in Ghana who used the Esoko platform, a mobile and webenabled service that allows farmers to check current market prices and sell their farm produces, had their revenue increased by 10\%. Anyan and Frempong (2018) also highlighted the importance of ICTs in disseminating agricultural information, especially in times of emergencies, which can help farmers prepare on time and facilitate the prevention or treatment of crop or animal diseases. They also emphasized that access to these types of information empowers farmers to make informed decisions such as determining the right planting season and the type of crops that will do well on which soil. 


\subsection{Health sector}

Globally, the demand for healthcare services has resulted in the need to develop and organize efficient new ways of providing healthcare services. The current COVID-19 global crisis in a broader sense has revealed how individual nations, with their regional and district healthcare systems, cannot manage complicated diseases all alone. The need of integrated disease surveillance program networks that connect healthcare professionals and the healthcare system to be able to monitor disease trends and come up with solutions is apparent.

Most developing nations are expected to improve their ICTs in the form of e-health; hence, greater ICTs investment in the health sector is expected globally. Tomasi et al. (2004) observed how developed nations are ahead when it comes to utilization of e-health. E-health solutions, such as the development of electronics scheduling systems for appointments, examinations in hospital, and clinic admissions, and computerization of medical processes just to mention a few, has been seen implemented in developed countries. Developing nations lag when it comes to this approach; hence, there is a need to strengthen operations and expand delivery of public healthcare through e-health and an efficient and effective flow of information (Ouma \& Herselman, 2008).

\subsection{E-health and rural health}

Information is a necessary in the health sector. Appropriate application of ICTs can play a critical role by serving new and more efficient ways of accessing, communicating, and storing information in improving healthcare for individuals and communities. Eysenbach (2001) explained e-health as an emerging field where medical informatics, referral, public health, business, and information delivery are made efficient through the internet and appropriate ICTs. Various areas in the health sector of a developing nation's economy where ICTs can play a critical role have been identified (Ahamad \& Pandery, 2014; Ruxwana et al., 2010).

\subsubsection{Rural health}

Health researchers and rural health professionals require information to enhance healthcare systems in the rural areas of developing nations; however, information division exists between rural communities and urban areas (Ruxwana et al., 2010). In the medical field, errors such as loss of patient's medical records or issuance of wrong medicine due to wrong information can lead to loss of human life. Leveraging ICTs, for instance, through the 
Agyei Fosu | ASEAN Journal of Community Engagement | Volume 4, Number 2, 2020

development of databases will provide the capacity to improve rural health system efficiencies and prevent medical errors.

\subsubsection{Tele-education}

Continuous professional development is required in the healthcare sector for personnel to be better equipped with abilities for efficient address to problems. A tele-education that uses multivideo conference training systems, for instance, can be used to provide continuous training support for healthcare personnel in isolated rural areas.

\subsubsection{Tele-medicine}

Tele-medicine offers an opportunity for healthcare personnel in remote areas, alongside the use of ICTs devices such as cell phones, to make diagnostic inquiries and supply patient information to doctors and nursing personnel based in other health centres and hospitals to give appropriate feedback. This flexibility increases efficiency through enhanced connectivity and exchanged of knowledge that helps in preventing medical errors. Drones can be used to deliver medicines quickly to remote areas, thereby assisting in overcoming the problem of accessibility of remote areas, a typical issue developing nations face because of poor roads.

\subsection{Automation of production by manufacturing companies}

Most production companies in developing countries still depend on staff in terms of labor in manufacturing their products. Even with the ease of lockdown and curfew measures, most manufacturing companies in developing nations struggle to meet their daily production quota because of restriction on personnel that can be present at a company premises in each time. In addition, with social distancing still in effect, the total number of personnel within the premises is limited. As a result, most manufacturing companies realize the need for automation of production. This will consequently lead to investment in ICTs devices like robots in this sector.

\subsection{How leveraging technology is driving automation in the manufacturing sector in developing} nation's economy

Bessen (2019) observed how automation of production because of leveraging technology in the production sector of many developing nations' economy has led to an increase in productivity and job creation, as new workforce is required to operate the automation systems. Frey and Osborne (2017) also highlighted that artificial intelligence drives automation even in 
Agyei Fosu | ASEAN Journal of Community Engagement | Volume 4, Number 2, 2020

areas that are considered non-routine, such as housework. However, Beck et al., (2009) revealed that lack of capital prevents SMME manufacturers to invest in automation technologies or machineries.

\subsection{Rural development}

Access to developmental information and knowledge is critical in developing and improving livelihoods. As highlighted by Ahamad and Pandery (2014), development is not just about macroeconomic growth but, as the principle of equity states, that everyone including communities should be empowered through equitable and fair means to choose their own developmental path. Thus, one of the ways to empower people residing in rural areas is access to developmental information. This will help them make their own decisions regarding how to improve their livelihoods and determine their future developmental path. Rural areas in developing countries are confronted with several developmental problems; thus, there is a greater need to accelerate information to rural people for them to become active participants during developmental process.

The ICTs has proven its importance in rural development as it acts as a catalytic intervention by accelerating access to information that are critical to economic development and bridges the information gap within the rural setting. Therefore, leveraging ICTs and ICTs investment are paramount in promoting prosperity in the economic development, including social, cultural, and political aspects of developing countries.

\section{Conclusion}

To address the questions raised by the author for reflection in the abstract, certain trends from the current COVID-19 crisis that will fuel ICTs investment in certain sectors at play in developing nations' economy were identified. The pandemic has revealed the need for integrated disease surveillance program networks in the health sector that connect healthcare professionals in national, regional, and in districts to monitor disease trends and come up with necessary solutions. For developing nations to achieve this, it is paramount for non-negotiable ICTs infrastructure investments in the health sector.

In the education sector, the measure of e-learning taken to curb the crisis exposed the inability of higher education institutions in developing countries to offer teaching and learning to students outside the four walls of their campuses, which is due to the lack of proper educational technologies infrastructure. Hence, there is a need to invest in ICTs infrastructure 
Agyei Fosu | ASEAN Journal of Community Engagement | Volume 4, Number 2, 2020

to support e-learning during the COVID-19 pandemic, as displayed by some institutions in developed countries.

Second, the pandemic has revealed how manufacturing sectors in developing countries also need automation of some of its production work, thus, the need for leveraging and ICTs infrastructure investment. Furthermore, some of the challenges facing rural population in developing countries require ICTs investment and ICTs leveraging to address some of the challenges. In this article, the researcher, supported with literature, has presented insights into some non-avoidable implication changes in terms of ICTs investment to foster development in economic sectors in developing nation's economy, which serves as a lens through which ICTs investment is viewed as an agent that fosters economic growth for developing nations' economy in the 21st century global digital economies revolution. The current COVID-19 pandemic has also served as a lens, bringing into focused, especially for developing nation's government, business leaders, planners, policy developers, and agent of change, the need for integration and investment of ICTs in various sectors within the economy to foster growth and economic development.

\section{Author Contribution}

Agyei Fosu conceived of the presented idea as well as the approach of writing the final manuscript.

\section{References}

Ahamad, T., \& Pandery, J. K. (2014). A study on application and role of ICT in rural development. Journal of Emerging Technologies and Innovative Research, 1(6), 455-458.

http://www.jetir.org/papers/JETIR1406016.pdf

Al-Fahad, F. N. (2009). Students' Attitudes and Perceptions towards the Effectiveness of Mobile Learning in King Saud University, Saudi Arabia. The Turkish Online Journal of Educational Technology, 8(2), 84-101. https://eric.ed.gov/?id=ED505940

Alias, N. A., \& Rahman, N. S. N. A. (2005). The supportive distance learning environment: A study on the learning support needs of Malaysian online learners. European Journal of Open, Distance and E-Learning, 8(2), 1-14.

https: / /www.eurodl.org/?p=archives\&sp=full\&year=2005\&halfyear=1\&abstract=185 
Alshara, 0., \& Alsharo, M. (2007). E-learning and the educational organizations structure reengineering (EOSR). International Journal of Emerging Technologies in Learning, 2(3), 40-45. https://www.learntechlib.org/p/45043/

Anyan, F. Y., \& Frempong, G. (2018). An investigation into barriers that hinder the effective use of ICT in farming by small scale farmers in Asuogyaman District, Ghana. International Journal of Humanities, Social Science and Education, 5(1), 23-32.

https://dx.doi.org/10.20431/2349-0381.0501005

Asampana, I., Akanlisikum Akanferi, A. A., \& Ami-Narh, J. (2017). Reasons for poor acceptance of web-based learning using an LMS and VLE in Ghana. Interdisciplinary Journal of Information, Knowledge, and Management, 12, 189-208. https://doi.org/10.28945/3742

Beck, T. Demirgüç-Kunt, A., \& Honohan, P. (2009). Access to Financial Services: Measurement, Impact, and Policies. The World Bank Research Observer, 24(1), 119145. https://doi.org/10.1093/wbro/lkn008

Bessen, J. E. (2016). How computer automation affects occupations: technology, jobs and skills. Boston University School of Law \& Economics Working Paper No. 15-49. https://dx.doi.org/10.2139/ssrn.2690435

Bessen, J. E. (2019). Automation and jobs: When technology boosts employment. Economic Policy, 34(100), 589-626. https://doi.org/10.1093/epolic/eiaa001

Bohara, A. (2003). Strategic implementation of ICTs in agriculture information dissemination: A case of Gulmi Districts. Proceedings of IOE Graduate Conference, pp. 61-75. http://conference.ioe.edu.np/publications/ioegc2014/IOE-CONF-2014-08.pdf

Calitz, M. G. (2000). Guidelines for the training content of teacher support teams [Doctoral dissertation, Stellenbosch University]. SUNScholar Research Repository. http://scholar.sun.ac.za/handle/10019.1/51783

Chavula, H. K. (2013). The role of ICT in agricultural production in Africa. Journal of Development and Agricultural Economies, 6(7), 279-289.

https://doi.org/10.5897/JDAE2013.0517

Chhachhar, A. R., Qureshi, B., Khushk, G. M., \& Shakil, A. (2014). Impact of information and communication technologies in agriculture development. Journal of Basic and Applied Scientific Research, 4(1), 281-288.

http://www.academia.edu/download/32957462/Impact_of_Information_and_Communic ation_Technologies_in_Agriculture.pdf 
Agyei Fosu | ASEAN Journal of Community Engagement | Volume 4, Number 2, 2020

Dahlman, C. J. 1992. "Information technology strategies: Brazil and the East Asian newly industrialising economies". In High technology and Third World industrialisation: Brazilian computer policy in comparative perspective, Edited by: Evans, P. B., Frischtak, C. R. and Tigre, P. B. pp. 38-81. Berkeley: University of California Press.

Das, B. (2013). Diffussion of old information and communication technologies in disseminating agricultural knowledge: An analysis of farmers' income. African Journal of Science, Technology, Innovation and Development, 13(3), 1-13.

https://doi.org/10.1080/20421338.2013.817044

Desai, M. S., Hart, J., \& Richards, T. C. (2008). E-learning: Paradigm shift in education. Education, 129(2), 327-334. https://eric.ed.gov/?id=EJ871567

Eysenbach, G. (2001). What is e-health? Journal of Medical Internet Research, 3(2), E20. https://www.jmir.org/2001/2/e20/?newDesign

Farrell, G. (2001). The changing faces of virtual education. Vancouver, Canada: The Commonwealth of Learning. https://eric.ed.gov/?id=ED464236

Fosu, A. (2017). Technology versus quality education in an underdeveloped region: A case study of UNISA students in former Ciskei homeland in Eastern Cape. Informing Science: International Journal of Community Development \& Management Studies, 1, 1-11. https://www.informingscience.org/Publications/3757?Type=JournalArticles\&JournalID $=54 \&$ Volume $=1-2017$

Fosu, A. (2019a). E-learning and Conventional Learning in 21st Century Information Age: A Case Study of Students from Selected Universities in Buffalo City Metropolitan Eastern Cape South Africa. International Journal of Community Development \& Management Studies, 3, 31-41.

https://www.informingscience.org/Publications /4394?Type=JournalArticles\&JournalID $=54 \&$ Volume $=3-2019$

Fosu, A. (2019b). Readiness of Universities for the 21st Century digital economies: A look at selected lecturers from Universities in Buffalo City Metropolitan in Eastern Cape Province South Africa. International Journal of Community Development \& Management Studies, 3, 65-77.

https://www.informingscience.org/Publications /4454?Type=JournalArticles\&JournalID $=54$ 
Frempong, G., \& Anyan, F. Y. (2018). Use of ICT in farming by small scale farmers in Asuogyaman District, Ghana. International Journal of Humanities Social Sciences and Education, 5(1), 2332.

https://www.informingscience.org/Publications /4454?Type=JournalArticles\&JournalID $=54$

Frey, C. B., \& Osborne, M. A. (2017). The future of employment: How susceptible are jobs to computerisation? Technol. Forecast. Social Change, 114, 254-280.

https://doi.org/10.1016/j.techfore.2016.08.019

Halewood, N. J., \& Surya, P. (2012): Mobilising the Agricultural Value Chain in 2012, Information and Communication for Development - Maximising Mobile, elibrary.worldbank.org. Page 51. https://elibrary.worldbank.org/doi/abs/10.1596/9780-8213-8991-1\#page=51

Hanna, N. (1994). Exploiting information technology for development: A case study of India. World Bank Discussion Paper 264. Washington, DC: World Bank. http://documents.worldbank.org/curated/en/945651468771641487/Exploitinginformation-technology-for-development-a-case-study-of-India

Hassan, M. S., Shaffril, H. A. M., Abu Samah, A., Abu Hassan, M., \& Ismail, N. (2009). Internet usage and its contribution towards agri-based productivity in Peninsular Malaysia. Jurnal Ilmu-Ilmu Sosial, 10, 1-9.

Hodgkinson-Williams, C., Slay, H., \& Sieborger, I. (2008). Developing communities of practice within and outside higher education institutions. British Journal of Educational Technology, 39(3), 433-442. https://doi.org/10.1111/j.1467-8535.2008.00841.x

Inal, Y., Karakus, T., \& Cagiltay, K. (2008). Turkish High School Students' Considerations, Expectations and Awareness on Distance Education. Turkish Online Journal of Distance Education, 9(4), 14. https://eric.ed.gov/?id=EJ816480

Jayathilake, H. A. C. K., Jayaweera, B. P. A., \& Waidyasekera, E. C. S. (2008). ICT adoption and its implications for agriculture in Sri Lanka. Journal of Food and Agriculture, 1(2), 54-63. https://jfa.sljol.info/article/1799/

Katengeza, S. (2012). ICTs-based market information services, operational environment and performance: The case of Malawi Agricultural Commodity Exchange and Food and Nutrition Security Joint Task Force. American International Journal of Social Science, 1(2), 34-43. https://aijssnet.com/journals/Vol_1_No_2_December_2012/4.pdf 
Agyei Fosu | ASEAN Journal of Community Engagement | Volume 4, Number 2, 2020

Kinuthia, W., \& Dagada, R. (2008). E-learning incorporation: An exploratory study of three South African higher education institutions. International Journal on E-learning, 7(4), 623639. https://www.learntechlib.org/p/24339/

Macedo-Rouet, M., Ney, M., Charles, S., \& Lallich-Boidin, G. (2009). Students' performance and satisfaction with Web vs. paper-based practice quizzes and lecture notes. Computers and Education, 53(2), 375-384. https://doi.org/10.1016/j.compedu.2009.02.013

Maina, M. K., \& Nzuki, D. M. (2015). Adoption determinants of e-learning management system in institutions of higher learning in Kenya: A Case of selected universities in Nairobi Metropolitan. International Journal of Business and Social Science, 6(2), 233-248. http://business.ku.ac.ke/images/stories/docs/adoption_determinants_of_elearning.pdf

Marfo, J. S., \& Okine, R. K. (2010). Implementation of e-learning in Ghanaian tertiary Institutions (A Case Study of KNUST). Paper presented at the Fifth Conference of MIT's Learning International Networks Consortium.

Mody, A., \& Dahlman, C. (1992). Performance and potential of information technology: An international perspective. World Development, 20(12), 1703-1719.

https://doi.org/10.1016/0305-750X(92)90086-B

Morales-Gómez, D., \& Melesse, M. (1998). Utilising information and communication technologies for development: The social dimensions. Information Technology for Development, 8(1), 3-13. https://content.iospress.com/articles/information-technologyfor-development/itd039

Murphy, D., Walker, R., \& Webb, J. (2001). Online learning: Teaching with technology. London: Kogan.

Nyamba, S. Y., \& Mlozi, M. R. S. (2012). Factors influencing the use of mobile phones in communicating agricultural information: A case of Kilolo Districts, Iringa, Tanzania. International Journal of Information and Communication Technology Research, 2(7), 558563. www.suaire.sua.ac.tz/handle/123456789/1786

Nzonzo, D., \& Mogambi, H. (2016). An analysis of communication and information communication technologies in irrigated rice production in Kenya. International of Education and Research, 4(1), 295-315.

http://ijern.com/journal/2016/December-2016/23.pdf

Odedra-Straub, M., ed. (1996). Global information technology and socioeconomic development. Nashua, NH: Ivy League. 
Oluoch, J., \& Osida, J. (2015). ICTs and technological development in advancing tea research in

Kenya. Journal of International Academic Research for Multidisciplinary, 3(2), 96-106. https://karuspace.karu.ac.ke/handle/20.500.12092/1809

Ouma, S., \& Herselman, M. E. (2008). E-health in rural areas: Case of developing countries. International Scholarly and Scientific Research \& Innovation, 2(4), 304-310. https://www.researchgate.net/profile/Marlien_Herselman/publication/290364319_Ehealth_in_rural_areas_Case_of_developing_countries/links/569cc2d208aed091d774d6a1 /E-health-in-rural-areas-Case-of-developing-countries.pdf

Oxagile. (2016). History and Trends of Learning Management System [Infographic]. https://www.oxagile.com/article/history-and-trends-of-learning-management-systeminfographics/

Phillipo, J., \& Krongard, S. (2012). Learning Management System (LMS): The missing link and great enabler. Massachusetts ASCD Perspectives, 1-7.

https://www.academia.edu/24441573/Learning_Management_System_LMS_The_Missin g_Link_and_Great_Enabler

Qteishat, M., \& Alshibly, H. (2013). Factors Influencing the Adoption of E-Learning in Jordan: An Extended TAM Model. European Journal of International Management, 5, 84-100. https://www.researchgate.net/profile/Haitham_Alshibly/publication/269635743_Facto rs_Influencing_the_Adoption_of_E-

Learning_in_Jordan_an_Extended_TAM_Model/links/54911df10cf225bf66a9a041.pdf

Randeree, K. (2008). Managing organizational change: Challenges to the e-learning paradigm in the United Arab Emirates. International Journal of Learning, 14(10), 41-46. https://cgscholar.com/bookstore/works/managing-organizational-change

Rosenberg, M. (2001). E-learning: Strategies for delivering knowledge in the digital age. New York: McGraw-Hill.

Ruxwana, N. L., Herselman, M. E., \& Conradie, D. P. (2010). ICT applications as e-health solutions in rural healthcare in the Eastern Cape Province of South Africa. Health Information Management: Journal of the Health Information Management Association of Australia, 39(1), 17-26. https://doi.org/10.1177\%2F183335831003900104

Seena, J. (2010). An investigation into the impact of e-learning on information technology students at further education and training schools in Mthatha. Unpublished BTech dissertation. East London, South Africa: Walter Sisulu University. 
Agyei Fosu | ASEAN Journal of Community Engagement | Volume 4, Number 2, 2020

Sein, M. K., \& Harindranath, G. (2004). Conceptualizing the ICT artifact: Toward understanding the role of ICT in national development. The Information Society, 20(1), 15-24. https://doi.org/10.1080/01972240490269942

Stienen, J., Bruinsma, W. \& Neuman, F. (2007). How ICT can make a difference in agricultural livelihoods. The Commonwealth ministers book. Netherlands: International Institute for Communication and Development.

Syiem, R., \& Raj, S. (2015). Access and usage of ICTs for agriculture and rural development by the tribal farmers in Meghalaya State of North-East India. Journal of Agricultural Informatics, 6(3), 24-41. https://real.mtak.hu/29903/1/190_1024_1_PB_u.pdf

Tomasi, E., Facchini, L. A., \& Maia, M. F. (2004). Health information technology in primary health care in developing countries: A literature review. Bulletin of the World Health Organization, 82(11), 867-874. https://www.scielosp.org/article/bwho/2004.v82n11/867-874/en/

Tranfield, D., Denyer, D., \& Smart, P. (2003). Towards a methodology for developing evidenceinformed management knowledge by means of a systematic review. British Journal of Management, 14(3), 207-222. https://onlinelibrary.wiley.com/doi/abs/10.1111/14678551.00375

Webster, J., \& Watson, R. T. (2002). Analyzing the past to prepare for the future: Writing literature review. MIS Quarterly, 26(2), xiii-xxiii. https://www.jstor.org/stable/4132319

Wilson, G., \& Heeks, R. (2000). Technology, poverty and development. In Poverty and development: Into the 21st century, Eds. T. Allen and A. Thomas. Oxford: Oxford University Press, pp. 403-424.

Yosuf, S. (2001) Globalisation and the Chellenge for Developing Countries. World Bank Policy Research Working Paper No. 2618. [Online] Abstract from Social Science Research Network database. http://papers.ssrn.com/sol3/papers.cfm?abstract_id=632686

Zhao, J., McConnell, D., \& Jiang, Y. (2009). Teachers' conceptions of e-learning in Chinese higher education: A phenomenographic analysis. Campus-Wide Information Systems, 26(2), 90-97. https://doi.org/10.1108/10650740910946800 